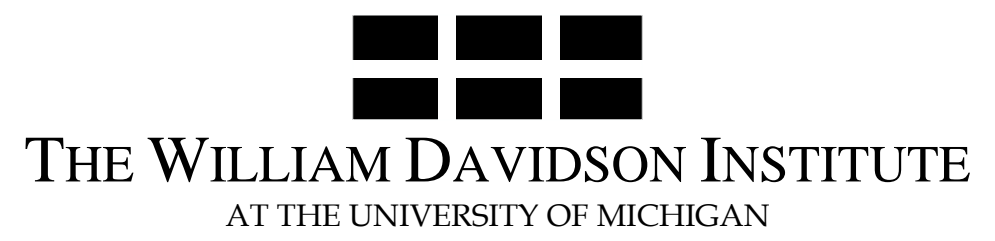

AT THE UNIVERSITY OF MICHIGAN

\title{
THE EFFECTS OF NETWORK'S STRUCTURAL HOLES: POLYCENTRIC INSTITUTIONS, PRODUCT PORTFOLIO, AND NEW VENTURE GROWTH IN CHINA AND RUSSIA
}

\author{
By: Bat Batjargal
}

William Davidson Institute Working Paper Number 1033

May 2012 
Structural holes

THE EFFECTS OF NETWORK'S STRUCTURAL HOLES: POLYCENTRIC INSTITUTIONS, PRODUCT PORTFOLIO, AND NEW VENTURE GROWTH IN CHINA AND RUSSIA

\author{
BAT BATJARGAL \\ Harvard University \\ Davis Center \\ 1730 Cambridge Street \\ Cambridge, MA 02138 \\ batjarg@fas.harvard.edu
}

Keywords: entrepreneurship, networks, institutions, Russia, China

JEL codes: L26, L29, L86, P20

Strategic Entrepreneurship Journal, 2010, 4 (2): 146 - 163. 


\section{THE EFFECTS OF NETWORK'S STRUCTURAL HOLES: POLYCENTRIC INSTITUTIONS, PRODUCT PORTFOLIO, AND NEW VENTURE GROWTH IN CHINA AND RUSSIA}

This study examines the effect of network's structural holes, i.e., the absence of a link between two contacts who are both linked to an actor, on product development and profit growth of software ventures in two different institutional contexts of China and Russia. Using interview data of 159 software entrepreneurs in Beijing and Moscow, the study found that the effect of structural holes is contingent upon country institutional context and venture development stage. Specifically, structural holes have a positive main effect on product portfolio but a negative main effect on profit growth in the second revenue year - early stage of venture development. Structural holes are more useful in the Russian institutional context compared to the Chinese institutional context due to the polycentricity of institutions. The research implications of the findings are discussed. 
Structural holes

The network concept of structural holes defined as the absence of a link between two contacts who are both linked to an actor has become a popular notion in the social capital research (Brass et al., 2004; Burt, 1992). The networks rich in structural holes were referred to as entrepreneurial networks, and the person who profits from structural holes is regarded as an entrepreneur in the literal sense (Burt, 1992: 34). The previous studies of structural holes in managerial networks produced contradictory results. On the one hand, scholars found that structural holes have a positive effect on managerial career and entrepreneurial success (Batjargal, 2007a; Burt, 1992; 2004; Podolny and Baron, 1997), and on the other hand, researchers documented that structural holes hinder managerial promotion (Podolny and Baron, 1997; Xiao and Tsui, 2007). Meanwhile, institutional theorists argue that the way in which networks affect dependent variables is embedded in local institutional contexts (Ostrom, Schroeder and Wynne, 1993). Will institutional diversity and polycentricity explain the effect of network’s structural holes on dependent variables?

Prior research on structural holes in managerial networks examined this phenomenon exclusively in a single country context, for example, United States (Burt, 1992) or China (Xiao and Tsui, 2007).Therefore, one of the reasons for conflicting findings of the previous studies may be that it did not reflect diverse institutional contexts across countries in which networks are built, maintained and mobilized. Given the tremendous institutional diversity around the world (Ostrom, 2005), would the effects of structural holes on entrepreneurial success be different across countries?

As an attempt to provide a partial answer to this question, the current study examines the role of structural holes in entrepreneur's networks in product development 
Structural holes

and financial performance of new ventures in the comparative contexts of China and Russia. Thus, the main objective of this study is consistent with a recent call for more local context-specific research of international entrepreneurship (Cumming et al., 2009).

The extant research on entrepreneurial networks largely focused on interorganizational networks (Baum, Calabrese, and Silverman, 2000; Stam, 2010; Stuart, Hoang and Hybels, 1999; Stuart and Sorenson, 2007), entrepreneurial team networks (Aldrich and Kim, 2007; Eisenhardt and Schoonhoven, 1996; Ruef, Aldrich, and Carter, 2003), and entrepreneur’s network size and composition (Batjargal, 2000; 2003a;

Renzulli, Aldrich, and Moody, 2000). In contrast to previous studies, I examine the effect of structure of personal networks of entrepreneurs on new venture product portfolio, i.e., the number of software products developed for different product-market segments, and profit growth. Specifically, I address the following three questions. First, do network's structural holes affect product development and profit growth of new ventures? Second, do national institutions (i.e., Chinese versus Russian) moderate the effect of structural holes on product portfolio of new ventures? Third, does product portfolio of new companies moderate the effect of structural holes on profit growth?

Drawing on social network theory and the institutional diversity literature (North, 2005; Ostrom, 2005), I propose hypotheses on structural holes, product portfolio, and profit growth of new ventures in China and Russia. I use telephone interview data of 159 entrepreneurs - founder-CEOs of software ventures that are 6 years old and younger. In order to study the effects of structural holes in non-Western and cross-country contexts, I have interviewed software entrepreneurs in China and Russia, two large emerging 
Structural holes

economies with divergent institutional trajectories (Batjargal, 2007b; 2007c; Djankov et al., 2006; Hitt et al., 2004; North, 2005; Scott, 2000; Shleifer, 2005).

The main contributions of this study are twofold. First, this study argues that the effect of structural holes on dependent variables is moderated by polycentric institutions. The concept of polycentric institutions refers to a system where actors are able to organize not just one but multiple governance rules at differing scales rooted in local beliefs, knowledge, and situations (Ostrom, 2005; Ostrom, Schroeder and Wynne, 1993). The divergent institutional transformations in China and Russia are resulted in different institutions or polycentric institutions in the two countries. This is a relatively new theoretical idea in management and entrepreneurship research. By examining structural holes, product portfolio and profit growth in China and Russia, this study compares entrepreneurs and entrepreneurial processes in two different institutional environments. Therefore, this study makes both theoretical and empirical contributions to the emergent literature on international entrepreneurship (Cumming et al., 2009). Second, by exploring main and indirect (interaction) effects of network's structural holes on dependent variables, the article contributes to the structural holes argument of social network theory because it identifies boundary conditions for structural hole effects.

This article is structured as follows. In the next section, I describe the institutional diversities in China and Russia. In the conceptual framework, I propose four hypotheses. This is followed by the methods part. In this section, I describe the software industries in the two countries, the survey data, the variables and measurements, and the construct validation procedures. In the results section, I report the findings and the robustness analyses. In the discussion part, I discuss the contributions, the implications, and the 
Structural holes

limitations of this study. The conclusion section summarizes the findings and their implications.

\section{INSTITUTIONAL POLYCENTRICITY IN CHINA AND RUSSIA}

Institutions are defined as multifaceted, durable social structures composed of regulative, normative, and cultural-cognitive elements (Scott, 2001). Institutional transformation is regarded as changes in the formal regulations and informal social norms that influence actors’ behaviors (North, 1990). China and Russia as emerging economies are experiencing unprecedented institutional changes. This institutional transformation is characterized as a dual process: On the one hand, it is a deinstitutionalization process that is reflected in the erosion and discontinuity of institutionalized organizational activities and practices (Oliver, 1992). On the other hand, this is an institutionalization process that is reflected in the growth of novel regulative rules and norms that facilitate or constrain actors’ behaviors (Scott, 2001). Deinstitutionalization refers to the delegitimization of established rules, structures, and organizations. Specifically, deinstitutionalization is the process by which the existing structures, organizations and norms are rejected, discredited and dismantled due to the political, economic, and social pressures (Oliver, 1992). On the contrary, institutionalization is the creation and legitimization of new and emerging regulations, organizations, and norms. Institutionalization is the process by which growing regulative, normative, and organizational elements gain appropriateness, acceptance, and creditability. Therefore, institutionalization is driven by the rule-setting, the self-reinforcing feedback dynamics of legitimacy, and the taken-for-grantedness of novel systems and organizations (Colyvas and Powell, 2006). 
Structural holes

Although the dual processes of institutionalization and deinstitutionalization occurred in China and Russia simultaneously in the 1990s, the Chinese transformation may be characterized as a gradual institutionalization process, whereas the Russian transition may be described as a rapid deinstitutionalization process (North, 2005; Scott, 2000). These divergent institutional transformations result in polycentric institutions when formal and informal rules are embedded in unique local beliefs, knowledge, and settings (Ostrom, 2005). The polycentric institutions are reflected in diverse social networks and relations, and these effects are stronger in emerging economies (Ostrom et al., 1993).

In contrast to Russia, China has adopted the reform path of gradualism that resulted in the limited political reforms, staged economic liberalization, and sequenced privatization. The Chinese leadership carried out simultaneous political centralization and economic and fiscal decentralization (Shleifer, 2005). China's communist institutions were not discredited. On the contrary, they were reformed and revitalized, and arguably, gained some legitimacy among at least the Han Chinese majority in China. The Chinese Communist Party abandoned the ideology of peasant dictatorship and class struggle, and admitted private entrepreneurs to broaden its social base. While the Chinese communist party has consolidated its absolute dominance of the legislature, judiciary, media, security forces, and military, it effectively transferred power in areas of economy, education, and culture to non-party bureaucracies. The newly emerging organizations such as regulatory agencies, financial institutions, and private firms are trusted to a certain degree in China. In this way, the dual processes of the emergence of new rules and the survival of the old institutions provided China with relative institutional stability. Thus, China blends communist political system with capitalist market economy. The rising institutional 
Structural holes

framework in China is of a hybrid type of communist-capitalist regulations, organizations and informal norms (Nee, 1992; Scott, 2000).

In contrast to China, Russia has chosen the path of rapid political and economic liberalization, and massive privatization of state-owned enterprises. Russia quickly replaced the communist political system by a multi-party system, and carried out political decentralization that shifted much of the political power from the center to local governments (Shleifer, 2005). Furthermore, the Russian federal government introduced a series of rules and mechanisms that were designed to control Russia’s regions fiscally through new systems of budget and taxation. While the Russian political reforms in the 1990s dismantled the Soviet-type rules and organizations, they did not create effective democratic and market-oriented norms, structures, and organizations. For example, the Russian financial institutions and oligarchic firms that grabbed assets through the privatization schemes in the middle of 1990s are widely distrusted and despised because of the persistent economic crises, inflation, and corruption (Goldman, 2003; Spicer and Pyle, 2002). While Vladimir Putin's centralization policies in the 2000s brought some stability to the Russian institutions, it failed to build and nurture sustainable economic regulations and norms (Goldman, 2008; North, 2005). Thus, the institutional framework in Russia can be characterized as a setting where the old regulations and organizations were dismantled but the new rules and structures are ineffective and illegitimate.

The absence of formal rules or the presence of dysfunctional regulations leads to the rise of informal norms and networks that generate relatively stable environments for economic actors (North, 1990; Ostrom et al., 1993). Both China and Russia have unique informal institutions of guanxi (connections) networks and svyazi (connections) networks 
Structural holes

accordingly (Batjargal, 2007c; 2008; 2010; Xin and Pearce 1996). Scholars found that Chinese guanxi ties facilitate job mobility (Bian, 1997), enhance firm performance (Batjargal, 2003b; 2007a; Park and Luo, 2001) and enable entrepreneurs to raise venture capital (Batjargal and Liu, 2004). Likewise, Russian svyazi relationships reduce uncertainties in financial transactions (Guseva and Rona-Tas, 2001), enhance firm performance (Batjargal, 2003c; 2005; 2006) and facilitate entrepreneurs’ access to resources (Sedaitis, 1998).

I expect that the relative institutional stability in China and group-oriented norms of guanxi may create conditions where structural holes will not facilitate product development. On the contrary, the institutional void (Khanna and Palepu, 2000) prevailing in Russia as a reflection of deinstitutionalization and highly context specific features of svyazi norms moderate positively the effects of structural holes on product development of new ventures.

\section{CONCEPTUAL FRAMEWORK AND HYPOTHESES}

The theory of structural holes states that actors with networks rich in structural holes reap two types of benefits: access to information, and control through brokerage (Burt, 1992:

13). The information benefit is the timely access to nonredundant information, opportunities, referrals and resources. The brokerage benefit is the power, information control, and resource gains of the third party from playing two actors against one another.

Consistent with these assumptions, I propose that structural holes in entrepreneur's personal networks facilitate product development (portfolio) of software ventures through several mechanisms: timely access to nonredundant information and referral sources, discovery of new opportunities and resources in distant network clusters, combination of 
Structural holes

diverse knowledge and technology (Hargadon and Sutton, 1997), and the transitivity mechanism when the entrepreneur links directly two previously unconnected ties (Granovetter, 1983).

The access to nonredundant information exposes venture founders to diverse technological, product design and market information located in socially and geographically distant network clusters (Schach, 2002). Software entrepreneurs learn from bridging ties what applications are demanded and favored in different market niches, and what modules, functions, design features, algorithms and languages are combined and used in what ways to produce various applications in technically novel yet cost efficient ways (Stam, 2010).

Third-party referrals help venture founders to access greater pools of actors who generate diverse information (Batjargal and Liu, 2004). The referees as information filters reduce search and deployment cost of information gathering (Burt, 1992). The matching principle in referral practices, i.e., connecting two actors whose interests are similar, helps software developers to access the desirable codes and design elements at the right time (Fernandez, Castilla and Moore, 2002).

By mobilizing low-density networks that contain numerous structural holes, entrepreneurs identify and exploit opportunities to form external alliances (Eisenhardt and Schoonhoven, 1996) and embed their programs in hardware and middleware systems of other producers. Entrepreneurs who spin boundaries of fragmented domains of ideas, artifacts and people (Hargadon and Sutton, 1997) re-combine creatively various software elements to produce new programs. 
Structural holes

Network transitivity may be beneficial to software development. Transitivity is a property that considers patterns of triples of actors in a network. A triad is transitive if every time AB relation and AC relation leads to BC relation (Granovetter, 1983). Transitive property enables entrepreneurs to link previously disconnected software engineers to write new programs. Based on these discussions, I propose:

Hypothesis 1: Structural holes in entrepreneur's networks have a positive effect on product portfolio (number of software products) of new ventures.

In the following section, I contrast the moderating role of Chinese and Russian polycentric institutions in the relationship between structural holes and product portfolio. I propose that the effect of structural holes on product portfolio will be stronger in Russia than in China for two reasons. First, the Russian institutional transformation generates more structural holes in networks and greater opportunities for entrepreneurial brokerage compared to China (Batjargal, 2007c; Blanchard and Kremer, 1997; Sedaitis, 1998). Second, the informal social norms in Russia encourage brokerage activities in contrast to China where the traditional values and norms regard brokering as opportunistic and selfish that is needed to be sanctioned (Frye, 2000; Hofstede and Bond, 1988; Ledeneva, 1998; Xiao and Tsui, 2007). Thus, Russian entrepreneurs are likely to benefit more from structural holes than Chinese entrepreneurs who have fewer brokerage opportunities and whose social costs of spanning structural holes are likely to be higher.

The Russian institutional reforms resulted in the comprehensive restructuring of the existing organizations, regional and industry-wide networks, and professional associations (Blanchard and Kremer, 1997). The dismantling of the massive Soviet bureaucracies, privatization of state-owned enterprises, layoffs, and downsizing lead to 
Structural holes

unemployment and displacement (Kharkhordin and Gerber, 1994). This forced Russian entrepreneurs to create new networks and clusters that serve as substitutes for nonexistent or weak institutions (Aidis, Estrin and Mickiewicz, 2008; Batjargal, 2003a; Sedaitis, 1998). This may have increased structural holes in networks over time. Arguably, Russian society is more mobile both geographically and occupationally because of the more liberalized labor market and the elimination of the Soviet residential permission system - propiska. Prior research has found that Russian entrepreneurs were more mobile than their Chinese counterparts (Djankov et al., 2006). This mobility has led to lowdensity networks that generated brokerage opportunities. Indeed, first private firms that emerged in the post-Soviet Russia were commodity exchanges where intermediaries brokered between commodity sellers - state-owned enterprises and buyers - new private firms (Batjargal, 1998; Frye, 2000). Therefore, brokerage is regarded as a legitimate business activity in Russia.

In contrast to Russia, the gradual institutionalization enabled Chinese entrepreneurs to preserve their work-related networks and build cohesive networks over time (Dai, 2002; Segal, 2003; Zhou, 2007). The institutional and organizational continuity reduced membership turnover in the Chinese networks. Social stability in China is conducive to sustainable socializations of actors and in this way, it made the networks of Chinese entrepreneurs redundant and overlapping. Further, the rigid residential permission system - hukou, and the state employment system - danwei in China constrain free flows and migrations of people including entrepreneurs between different localities. This restricts professional networking opportunities of Chinese entrepreneurs. In a survey study, Djankov et al., (2006) found that Chinese entrepreneurs 
Structural holes

had lived in fewer localities, and held fewer distinct professional positions than their Russian counterparts. In case of Chinese software entrepreneurs, Saxenian and Quan (2005) concluded that closed guanxi networks of software entrepreneurs with government officials and former employers (state-owned enterprises) hindered their firms' growth and development.

It is reasonable to assume that Russian and Chinese venture founders equally benefit from nonredundant information in dispersed networks. Therefore, the access to nonredundant information generates no gains or advantages for either groups of entrepreneurs relative to other. This mechanism of structural holes may not have as salient implications for venture success as control or brokerage when one compares Chinese and Russian ventures.

Chinese and Russian entrepreneurs perceive entrepreneurial brokerage differently. Brokerage is a process by which intermediary actors facilitate transactions between other actors lacking access to or trust in one another and gain power and resources by charging “commissions” each time they broker an exchange (Marsden, 1982). Social actors may prefer different roles in brokerage situations including that of the coordinator and integrator (Xiao and Tsui, 2007), and the controller who deliberately plays actors against one another and actively pursues the strategy of "the third who benefits" (Burt, 1992: 30). While the Russian entrepreneur plays the role of the controller in svyazi networks (Frye, 2000; Sedaitis, 1998), the Chinese entrepreneur rejects the control aspect of brokerage in guanxi networks (Batjargal, 2007a).

The Chinese entrepreneur may not be motivated as much as the Russian entrepreneur to play the role of the controller and generate gains from intermediary 
Structural holes

positions for a number of reasons. The controlling action that creates competition between sides and increases bargaining power of the central actor is not congruent with the Chinese manager's propensity to be more group-oriented relative to the Russian manager (Ralston et al., 1997). Chinese entrepreneurs are aware of the potential risks and negative reactions of other stakeholders to brokerage because it is regarded as exploitative in China (Batjargal, 2007c; Xiao and Tsui, 2007). The Chinese may not gain from brokerage as much as the Russians because they are likely to be less experienced and prepared to manipulate information and maximize power in the intermediary positions. These attributes often make Chinese entrepreneurs less willing to span structural holes. The lack of motivation to broker between contacts in turn is likely to reduce returns from networks for Chinese entrepreneurs. However, the cost of building and maintaining structural holes and bridging ties in networks is likely to remain unchanged (Burt, 1992). Thus, Chinese entrepreneurs bear the cost (time and resources) of bridge building and maintenance but benefit less from them because they do not engage in active brokerage, i.e., playing two actors against one another. In contrast, the Russians gain more because they benefit from both access to nonredundant information and brokerage. These outcomes produce network ineffectiveness and greater opportunity costs for the Chinese entrepreneurs.

When the Chinese entrepreneur chooses to play actors against one another and generate value from disunion, the returns may not be as high as those achieved by the Russian entrepreneur in similar situations. The Chinese entrepreneur's brokerage is perceived as illegitimate because many stakeholders, including software developers, suppliers and buyers, regard brokerage as an unethical and harmful action. The social 
Structural holes

disapproval of brokerage may tarnish reputation of Chinese brokers because Chinese networks tend to be more cohesive where members scrutinize each other's behavior intensely (Saxenian and Quan, 2005; Xiao and Tsui, 2007).

Chinese entrepreneurs who play the role of the controller in triads, i.e., triple actors, are likely to be penalized by other stakeholders because this violates the normative prescriptions of the Chinese to be group-oriented. This may be especially true if the controller is a new entrepreneur, and the others are more established players. This will substantially reduce material and intellectual gains from brokerage for Chinese business owners. Overall, Chinese entrepreneurs may not gain from network’s structural holes as much as Russian entrepreneurs because of the motivation and legitimacy constraints. This affects product development negatively for the Chinese entrepreneurs. Based on these discussions, I propose:

Hypothesis 2: The positive relationship between structural holes in entrepreneur's networks and product portfolio (number of software products) of new ventures will be stronger in Russia than in China.

Next, I propose that network's structural holes have a negative effect on profit growth of new ventures in the early stages of venture creation and development. At early stages of a venture life cycle, for example, second revenue year (Reynolds and White, 1997), structural holes in networks may hinder venture growth through the following three mechanisms. First, at the beginning, a nascent entrepreneur may have difficulties to coordinate among and communicate with various network members who do not know each other. This slows down decision-making to exploit new opportunities (Reynolds and White, 1997). Second, obtaining financial and knowledge resources from disconnected contacts requires more time and efforts because there is less trust among ties, and 
Structural holes

members feel less obliged to help (Batjargal, 2007a; Sedaitis, 1998). Third, although dispersed networks generate nonredundant information, contradictory, conflicting and sometimes even distorted information about market demand for software product and strategies of rival firms may prevent founders to formulate and implement consistent product development and sales strategies at the early stages (Coleman and Verbruggen, 1998; Schach, 2002). Thus, the coordination and communication difficulties, constrained resource mobilization, and unfocused strategies as a reflection of ambiguous information may hinder profit growth of new ventures in the early stages of development. I propose: Hypothesis 3: Network's structural holes have a negative effect on profit growth at the early stage (second revenue year) of new venture development.

Finally, I hypothesize that the negative effects of structural holes on profit growth are strengthened when new ventures develop numerous software products for various product-market segments. When entrepreneurs develop many software applications, the communication difficulties with socially distant software writers turn into confusion about product development priorities and piece-meal, uncoordinated actions that hinder venture growth (Schach, 2002). The constrained resource mobilization from distant ties and simultaneous development of several software applications are likely to spread limited knowledge and financial resources thinly across many product lines. This results in low quality, incomplete and incompatible software products that hard to sell and generate profits (Coleman and Verbruggen, 1998). The contradictory information about various market segments gathered from disconnected weak ties and unsynchronized efforts to expand product variety often result in inconsistent sales and marketing 
Structural holes

strategies and tactics. This is reflected in lower profit growth for entrepreneurs who have dispersed networks and large product portfolio. Therefore, I propose:

Hypothesis 4: The interaction effect of structural holes in entrepreneur's networks and product portfolio on profit growth will be negative at the early stage (second revenue year) of new venture development.

\section{METHODS}

\section{Software industry contexts}

The Chinese software industry. The roots of software firms in China are traced to four sources: research institutes of the Chinese Academy of Sciences, university research laboratories, $R \& D$ institutes of government ministries, and entrepreneurial startups. The total sales of software and system integration products in 2003 (the year when the interview data were collected) were worth US\$19.3 billion, a 45 percent growth year-onyear. By the end of 2003, there were 8582 domestic software vendors (People's Daily, 2004). Roughly 70 percent of these firms are small firms that employ fewer than 50 fulltime employees (Tschang and Xue, 2005). China’s software exports reached \$3.6 billion in 2002 (Business Weekly, 2003). China’s software industry grew at a compound annual growth rate of more than 39 percent over the period from 2001 to 2007 to reach RMB506 billion (Chinese currency - Yuan) and is further anticipated to grow of nearly 22 percent through 2012 (Software industry in China, 2008). Scholars emphasized the importance of both formal and informal (guanxi) institutions in software development in China (Saxenian and Quan, 2005; Tschang and Xue, 2005).

The Russian software industry. Russian software ventures resemble the Chinese firms in terms of origin, with two important differences. Like the Chinese vendors, many originated in the Soviet/Russian Academy of Sciences, university laboratories, and 
Structural holes

government R\&D institutions. In contrast to China, many successful software ventures are spin-offs from the Soviet/Russian military-industrial complex, which still produces advanced weaponry systems, including software. Most Russian vendors are private startup firms. The Russian IT industry including software grew at 30-40 percent annually from 2000 to 2006. Russian software exports grew from $\$ 120$ million in 2000 to $\$ 1.8$ billion in 2006, and Russia is the third largest software exporter after India and China (Economy of Russia, 2010). At the end of 2002, there were more than 2000 domestic software companies (Burgess and Travis, 2005). The average revenue growth of software makers was 50-60 percent in 2002 (Ekspert, 2003). Most Russian firms are small, employing fewer than 45 people and generating revenues about \$2.5 million a year.

\section{Sample and interview data}

I use a telephone survey data of 82 Russian entrepreneurs in Moscow and 77 Chinese entrepreneurs in Beijing. The interviews were conducted in June-October 2003. In total, 118 respondents were CEOs, and 41 respondents were chief technology officers (CTO). The technical directors were interviewed only in those occasions when the CEO was unavailable, director was a member of the founding team, and the firm has more than 50 full-time employees.

Collection of primary survey data of new ventures in emerging economies is a particular challenge in international entrepreneurship research (Cumming et al., 2009). I used the following four criteria to sample new, dedicated and domestic software ventures in China and Russia. First, venture must be 6 years old or younger to qualify as a new venture (Zahra, Ireland and Hitt, 2000). Second, firm should be registered as a software firm. Third, venture should be owned fully by domestic shareholders. Finally, I study 
Structural holes

software ventures in high tech regions, i.e., Beijing and Moscow, because of higher chances of sampling high-growth start-ups rather than self-employed entrepreneurs or low-growth, life-style businesses.

In China and Russia, there are no complete electronic and other data of new firms like, for example, the Dun and Bradstreet database in the United States. Therefore, my research assistants and I used varieties of information sources ${ }^{1}$, i.e., telephone directories, membership lists of local entrepreneurial associations, electronic databases, new venture directories of consulting and venture capital companies, and data bases of local governments, to identify new software firms. Although this sampling approach is less systematic, it enabled us to sample more and diverse ventures, and arguably, made our samples more random. We created a list of 111 new, dedicated and domestic ventures based in Moscow. The positive response rate for the Russian sample is 73 percent (82 entrepreneurs responded). In Beijing, we created a list of 172 ventures. The positive response rate for the Chinese sample is 44 percent (77 entrepreneurs responded). The overall response rate is 52 percent (159 entrepreneurs responded from the total of 283 entrepreneurs). This compares favorably with most network surveys (Marsden, 1990; 2005).

The questionnaire was designed in English. Teams of Chinese and Russian management professors translated it into Mandarin Chinese and Russian, and back translated the questionnaire. I pre-tested the questionnaire with three Russian and two Chinese entrepreneurs. Two research assistants and I conducted interviews in Moscow,

\footnotetext{
${ }^{1}$ The complete lists of sample sources in Russian, Mandarin Chinese, and English are available upon request from the author.
} 
Structural holes

and the team of six research assistants carried out interviews in Beijing. Each interview lasted approximately in 25 minutes.

\section{Measures}

Independent variables. There are two methodologies commonly used to measure personal (ego-centric) social networks: the name-generator and the position generator. The name generator has been used widely in the network literature (Burt, 1992; Marsden, 1990; 2005). Although less common than first method, the position generator methodology has also been used fruitfully in management research and sociology (Belliveau, O’Reilly and Wade, 1996; Lin and Dumin, 1986).

Both methodologies have their own strengths and weaknesses. The name generator method allows one to measure structural properties of networks, i.e., density and structural holes, more thoroughly than the position generator. In addition, the name generator enables one to track down changes in personal networks of individuals over time. However, the name generator method may be biased towards strong ties since people are likely to remember well the interactions with strong ties (Lin, 2001).

An advantage of the position generator method is that it captures occupational or positional characteristics of network members - alters. The method also enables one to collect data on strong and weak dyadic ties simultaneously (Lin, 2001). The downsides of the position generator are limitations to conduct thorough structural analysis of networks, e.g., calculation of network constraint and structural holes, and the potential bias of social desirability, i.e., respondents may overestimate the number of powerful, resourceful and prestigious contacts. 
Structural holes

In this study, I use the name generator method because the methodology enables me to capture structural holes in ego-centric networks of entrepreneurs. The question that was used to generate contact names is as follows: 'The next questions are about those with whom you often discuss issues related to software programming and design. Please name those persons with whom you have discussed software programming issues over the last six months.' Thus, the network content or type is the discussion network about software programming and design. This question generated maximum eight names. The question that captured network structure is: 'The next question is to describe the strength of relations between listed people. You do this by circling codes in the matrix below (See Appendix). This is a complex question, but it is essential to measuring of social networks - and answering the question is a simple task when taken one column at a time. Begin with the first person listed. Relations with the first person are listed in the third column. Indicate his or her relationship with the person in each row in one of three ways: Circle E if there is an especially close relation between the row person and the first person. Circle $\mathrm{D}$ if the row person and first person are distant in the sense that they rarely work together, are total strangers as far as you know, or do not enjoy one another's company. Leave E D blank to indicate that two people are neither distant nor especially close’ (Burt, 1992). Structural holes is measured as the percentage of 'distant' relationships of all possible relationships within network of each respondent. Burt's (1992) network constraint is often used to measure structural holes. I calculated structural holes as ' 1 minus network constraint score.' However, the percentage of 'distant' relationships provided stronger empirical results ${ }^{2}$. Therefore, I use this measurement. Institutions are measured by country dummy variables: China is coded as one, and Russia is coded as zero.

\footnotetext{
${ }^{2}$ The network constraint score and the regression analyses with structural holes measured as 1 minus network
} 
Structural holes

Dependent variables. Product portfolio is the number of product-market segments where the firm sold packaged software products and applications. The respondents were given a list of 14 market segments of packaged software, and were asked to indicate in which segments the firm sold packaged software. I measure packaged software products because they are standardized and clearly classified into groups. The fourteen product market segments include accounting software, general management, enterprise planning, customer relationship, supply chain, e-government, systems software, education, middleware, embedded software, database, general office, home software, and others (e.g., games, anti-virus, industrial, etc). I used software product classifications of the Chinese Software Industry Association, the China Software Union, the Russian National Software Development Association, the Russian Anti-software Piracy Association and published sources. These sources generated 11 overlapping product segments in two countries, and 3 non-overlapping segments were added to the list. The information suggests that software product markets are comparable in two countries. I employ this measurement for product portfolio for the following reasons: First, the goal of this study is to examine the number of products developed for different product-market segments rather than product diversification, and therefore, this measurement is consistent with the research objective. Second, the traditional entropy measurement of product diversification may not be appropriate for new ventures. Finally, a similar measurement for product portfolio has been used in a previous study (Rothaermel, Hitt, and Jobe, 2006). Profit growth is measured as the percentage of profit growth in the second revenue year. I measure profit growth in the second year of revenue generation because I 
Structural holes

theorized that structural holes and product portfolio will affect profit growth in the early stages of venture development.

Control variables. Firm age is the number of years from venture registration. Firm size is measured by the number of full-time employees. Venture capital is a binary variable of one if private equity was raised and zero otherwise. Ownership is a binary variable of one if the major shareholder is the respondent and zero otherwise (Zahra et al., 2000). Network size is the number of contacts named (Marsden, 1990; 2005).

Data and construct validity. In order to check the common methods bias and the social desirability bias, my research assistants made data cross-validation phone calls. During the interviews, we asked for phone numbers of one of the contacts listed. In all, 41 Chinese respondents and 28 Russian respondents provided phone numbers. Selecting every second on the list of 41 Chinese contacts, and every second and third on the list of 28 Russian contacts, we contacted 20 Chinese and 20 Russian contacts and asked each contact to describe her/his relationship with the person next on the list in terms of 'especially close,' ‘distant’ and 'neither especially close nor distant.' All 20 (100\%) Chinese answers and 17 (85\%) Russian answers were consistent with our data. This indicates that the measurement for structural holes is valid. To my knowledge, this study is one of the first studies that validated perceptions of the respondent of relationships among contacts by asking one contact to characterize his or her relationship with another contact. In order to validate profit growth data, I submitted the 2002 profit growth information of 15 randomly chosen firms in each city to the Department of Taxation of the Haidian district government in Beijing, and the Department of Taxation of the Moscow City Government in Russia. Chinese and Russian officials confirmed that the 
Structural holes

profit information of 12 (80\%) Chinese ventures and 11 (73\%) Russian firms were accurate. James, Demaree and Wolfe (1984) argued that an agreement of at least 80 percent between multiple raters is necessary to establish reliability. Therefore, I assume that the survey data has an acceptable level of reliability and validity.

\section{RESULTS}

Table 1 reports the descriptive statistics and Pearson's correlations for all variables of the total surveyed sample $(\mathrm{N}=159)$. It shows that the mean firm age is 3.33 years (S.D.=1.44), and firm size is 47 employees (S.D.=52). The Chinese and Russian ventures tend to hire more employees because labor is cheaper, and there are important financial and other incentives to generate jobs (Batjargal et al., 2009). Fifty-nine percent of the ventures are majority owned by the entrepreneur. Thirteen percent of the new firms raised venture capital. The findings on entrepreneur's age and education are consistent with the findings of other surveys of entrepreneurs in China and Russia (Batjargal et al., 2009; Djankov et al., 2006). The mean network size is 4.29 (S.D.=1.34) contacts and the mean percentage of structural holes is 28 (S.D.=0.28). The mean product portfolio is 2.27 (S.D.=1.68). The mean profit growth is 3.90 percent (S.D.=6.17).

Table 1. Descriptive statistics and Pearson's correlations ( $\mathrm{N}=159)$

\begin{tabular}{|c|c|c|c|c|c|c|c|c|c|c|c|}
\hline & Variables & $\mathrm{N}$ & $\mathrm{M}$ & S.D. & 1 & 2 & 3 & 4 & 5 & 6 & 7 \\
\hline 1 & Firm age & 159 & 3.33 & 1.44 & & & & & & & \\
\hline 2 & Firm size & 159 & 47 & 52 & $0.31 * *$ & & & & & & \\
\hline 3 & Ownership & 159 & 0.59 & 0.49 & -0.09 & $\begin{array}{c}- \\
0.28 * *\end{array}$ & & & & & \\
\hline 4 & Venture capital & 159 & 0.13 & 0.33 & 0.00 & $0.17 *$ & -0.09 & & & & \\
\hline 5 & Entrepreneur's age & 159 & 37 & 8.33 & 0.12 & -0.12 & $0.25 * *$ & -0.14 & & & \\
\hline 6 & $\begin{array}{l}\text { Entrepreneur's } \\
\text { education }\end{array}$ & 159 & 2.27 & 0.74 & 0.06 & 0.07 & 0.04 & $0.15 *$ & 0.08 & & \\
\hline 7 & Network size & 158 & 4.29 & 1.34 & 0.12 & $0.15^{*}$ & -0.08 & -0.02 & 0.08 & $0.18^{*}$ & \\
\hline 8 & Structural holes \% & 157 & 0.28 & 0.28 & $0.28 * *$ & -0.01 & 0.11 & -0.03 & -0.01 & 0.12 & $0.25 * *$ \\
\hline
\end{tabular}


Structural holes

\begin{tabular}{clcccc}
\hline 9 & Product portfolio & 158 & 2.27 & 1.68 & $0.25^{* *}$ \\
& & & & & \\
10 & Profit growth \% & 145 & 3.90 & 6.17 & 0.13 \\
11 & China & 159 & 0.48 & 0.50 & - \\
& & & & & $\begin{array}{c}0.29^{* *} \\
*\end{array}$ \\
\hline & & & & \\
& & & & \\
\hline & Variables & 8 & 9 & 10 \\
& & & & \\
\hline & & & & \\
9 & Product portfolio & $0.48^{* *}$ & & \\
10 & Profit growth \% & $-0.17^{*}$ & -0.07 & \\
11 & China & $-0.43^{* *}$ & - & 0.01 \\
& & & $0.55^{* *}$ & \\
\hline
\end{tabular}

$* p<0.05 ; * * p<0.01 ; * * * p<0.001$

Table 2 reports the One-way ANOVA results of the Chinese and Russian samples. It shows that the Chinese networks are smaller and contain fewer structural holes. The Chinese ventures are younger, larger, more likely to raise private equity, and have fewer software applications.

Table 2. Descriptive statistics and ANOVA of the Chinese and Russian samples

\begin{tabular}{|c|c|c|c|c|c|c|c|c|}
\hline & \multirow[t]{2}{*}{ Variables } & \multicolumn{3}{|c|}{ China } & \multicolumn{3}{|c|}{ Russia } & \multirow{2}{*}{$\begin{array}{c}\begin{array}{c}\text { ANOVA } \\
\text { Model }\end{array} \\
F\end{array}$} \\
\hline & & $\mathrm{N}$ & Means & S.D. & $\mathrm{N}$ & Means & S.D. & \\
\hline 1 & Firm age & 77 & 2.89 & 1.32 & 82 & 3.74 & 1.43 & $15.29 * * *$ \\
\hline 2 & Firm size & 77 & 55.48 & 54.67 & 82 & 40.34 & 49.33 & $3.36 \dagger$ \\
\hline 3 & Ownership & 77 & 0.50 & 0.50 & 82 & 0.68 & 0.46 & $5.24 *$ \\
\hline 4 & Venture capital & 77 & 0.19 & 0.39 & 82 & 0.07 & 0.26 & $5.22 *$ \\
\hline 5 & Entrepreneur's age & 77 & 36.14 & 6.99 & 82 & 39.18 & 9.22 & $5.42 *$ \\
\hline 6 & Entrepreneur's education & 77 & 2.27 & 0.89 & 82 & 2.26 & 0.56 & 0.01 \\
\hline 7 & Network size & 76 & 3.92 & 1.45 & 82 & 4.63 & 1.13 & $11.82 * * *$ \\
\hline 8 & Structural holes \% & 75 & 0.15 & 0.27 & 82 & 0.40 & 0.23 & $35.87 * * *$ \\
\hline 9 & Product portfolio & 76 & 1.31 & 0.73 & 82 & 3.16 & 1.82 & $67.75 * * *$ \\
\hline 10 & Profit growth \% & 67 & 4.02 & 7.30 & 78 & 3.79 & 5.06 & 0.05 \\
\hline
\end{tabular}


Structural holes

In Table 3, I present the results of the multiple linear regression analysis

predicting product portfolio and profit growth. Model 1 is the base model for product portfolio. The model is statistically significant $(F=3.86, p<0.01)$. Model 2 shows that structural holes in networks $(b=0.29, p<0.001)$ have a positive and statistically significant effect on product portfolio. While venture capital $(b=0.13, \mathrm{p}<0.05)$ has a positive effect on product portfolio, China dummy variable $(b=-0.43, \mathrm{p}<0.001)$ has a negative effect on product portfolio. The model is significant $(F=12.13, p<0.001)$. Hypothesis 1 is supported.

Table 3. Linear regression analysis: Structural holes, product portfolio, and profit growth of new software ventures $(\mathrm{N}=159)$

\begin{tabular}{|c|c|c|c|c|c|}
\hline \multirow[t]{2}{*}{ Variables } & \multicolumn{3}{|c|}{ Product portfolio } & \multicolumn{2}{|c|}{ Profit growth \% } \\
\hline & Model 1 & Model 2 & Model 3 & Model 4 & Model 5 \\
\hline \multicolumn{6}{|l|}{ Control variables } \\
\hline Firm age & $0.23 * *$ & -0.02 & -0.08 & $0.26 * *$ & $0.23 * *$ \\
\hline Firm size & -0.07 & 0.07 & $0.12 \dagger$ & -0.09 & -0.09 \\
\hline Ownership & 0.02 & -0.09 & -0.07 & 0.13 & 0.13 \\
\hline Venture capital & 0.08 & $0.13^{*}$ & $0.13 *$ & 0.12 & 0.12 \\
\hline Entrepreneur’s age & 0.05 & 0.07 & 0.06 & $-0.19 *$ & $-0.19 *$ \\
\hline Entrepreneur's education & -0.06 & -0.07 & -0.06 & -0.01 & -0.01 \\
\hline Network size & $0.29 * * *$ & 0.10 & 0.09 & $0.17 \dagger$ & $0.17 \dagger$ \\
\hline \multicolumn{6}{|l|}{ Independent variables } \\
\hline Structural holes \% & & $0.29 * * *$ & $0.71^{* * *}$ & $-0.30 *$ & $-0.29 *$ \\
\hline China & & $-0.43 * * *$ & -0.08 & -0.05 & -0.05 \\
\hline Product portfolio & & & & -0.05 & -0.05 \\
\hline \multicolumn{6}{|l|}{ Two-way interactions } \\
\hline Structural holes \% * China & & & $-0.52 * * *$ & & \\
\hline $\begin{array}{l}\text { Structural holes } \% * \text { Product } \\
\text { portfolio }\end{array}$ & & & & & -0.01 \\
\hline Model F & $3.86 * *$ & $12.13 * * *$ & $16.23 * * *$ & $2.11^{*}$ & $1.90^{*}$ \\
\hline
\end{tabular}


Structural holes

\begin{tabular}{lccccc}
\hline Adjusted $R$ square & 0.11 & 0.39 & 0.49 & 0.07 & 0.06 \\
$N$ & 156 & 156 & 156 & 143 & 143 \\
\hline
\end{tabular}

Values represent standardized $B$ coefficients. $\dagger p<0.1 ;{ }^{*} p<0.05 ;{ }^{* *} p<0.01 ;{ }^{* * *} p<0.001$. Model 3 illustrates that the interaction of structural holes and China dummy variable ( $b=-0.52, p<0.001$ ) has a negative and statistically significant effect on product portfolio. The model is significant $(F=16.23, p<0.001)$. Hypothesis 2 is supported. Model 4 shows that structural holes $(b=-0.30, p<0.05)$ have a negative and statistically significant effect on profit growth in the second revenue year. The model is significant $(F=2.11, p<0.05)$. Hypothesis 3 is supported. Model 5 reveals the interaction effect of structural holes and product portfolio on profit growth. The interaction effect is not statistically significant. The effects of entrepreneur's age $(b=-0.19, \mathrm{p}<.1)$ and structural holes $(b=-0.29, \mathrm{p}<0.05)$ on profits are negative and statistically significant. Network size ( $b=0.17, \mathrm{p}<0.1)$ and firm age $(b=0.23, \mathrm{p}<0.01)$ have positive effects on profit growth although the effect of network size is marginally significant. Hypothesis 4 is not supported.

\section{Robustness of the results}

In order to check the robustness of these findings, I carried out a number of additional statistical analyses. I compared the sample of all surveyed firms $(\mathrm{N}=159)$ with the nonsurveyed sample ( $\mathrm{N}=124)$ by firm age, location (address), and firm website. Location is measured as follows: those ventures that were located in Beijing's Haidian district (the so-called Zhongguancun high tech district) and Moscow's Yugo-Zapad, the area where most of Russia's prestigious universities and $R \& D$ institutes are located, are coded as one and the others as zero. Firm website is a dichotomous variable of one when the firm has a website, and zero when the firm has no website. Firm age, location and firm website are 
Structural holes

the three variables on which I have information for the total sample population $(\mathrm{N}=283)$.

The results of the ANOVA are presented in Table 4. The findings show that the surveyed firms were slightly older than the non-surveyed firms at the marginally significant level $(F=2.93 ; p<0.1)$. The differences in location and firm website are not statistically significant.

Table 4. Descriptive statistics and ANOVA of the total sample populations and interviewed samples $(\mathrm{N}=283)$

\begin{tabular}{lccccccc}
\hline & \multicolumn{3}{c}{ Interview } & & \multicolumn{2}{c}{ Non-interview } & $\begin{array}{c}\text { ANOVA } \\
\text { Model }\end{array}$ \\
& $\mathrm{N}$ & Means & S.D. & $\mathrm{N}$ & Means & S.D. & $F$ \\
& & & & & & & \\
Firm age & 159 & 3.33 & 1.44 & 124 & 3.06 & 1.17 & $2.93 \dagger$ \\
Location (address) & 159 & 0.83 & 0.37 & 124 & 0.83 & 0.37 & 0.01 \\
Firm website & 158 & 0.87 & 0.33 & 124 & 0.86 & 0.34 & 0.06 \\
\hline
\end{tabular}

$\dagger p<0.1 ;{ }^{*} p<0.05 ; * * p<0.01 ; * * * p<0.001$.

Table 5. Descriptive statistics and ANOVA of the total sample populations and interviewed samples by country $(\mathrm{N}=283)$

\begin{tabular}{|c|c|c|c|c|c|c|c|c|c|c|c|c|c|c|}
\hline & \multicolumn{7}{|c|}{ China } & \multicolumn{7}{|c|}{ Russia } \\
\hline & \multicolumn{3}{|c|}{ Interview } & \multicolumn{3}{|c|}{ Non-interview } & \multicolumn{2}{|l|}{ ANOVA } & \multicolumn{2}{|c|}{ Interview } & \multicolumn{3}{|c|}{ Non-interview } & \multirow{2}{*}{$\begin{array}{c}\text { ANOVA } \\
F \\
\end{array}$} \\
\hline & $\mathrm{N}$ & Means & SD & $\mathrm{N}$ & Means & SD & $F$ & $\mathrm{~N}$ & Means & $\mathrm{SD}$ & $\mathrm{N}$ & Means & SD & \\
\hline Firm age & 77 & 2.89 & 1.32 & 95 & 3.01 & 1.22 & .37 & 82 & 3.74 & 1.43 & 29 & 3.22 & .99 & 3.03† \\
\hline $\begin{array}{l}\text { Location } \\
\text { (address) }\end{array}$ & 77 & .84 & .36 & 95 & .83 & .37 & .04 & 82 & .82 & .37 & 29 & .82 & .38 & .00 \\
\hline Firm website & 76 & .89 & .30 & 95 & .86 & .34 & .38 & 82 & .85 & .35 & 29 & .86 & .35 & .01 \\
\hline
\end{tabular}

$\dagger p<0.1 ;{ }^{*} p<0.05 ; * * p<0.01 ; * * * p<0.001$.

In addition, I compared the interviewed sample with the non-surveyed sample within each country. The ANOVA results are presented in Table 5. The findings illustrate 
Structural holes

that the differences between the two samples within each city were not statistically significant except firm age in the Russian samples $(F=3.03 ; p<0.1)$.

Stuart and Sorenson (2007) documented that the endogeneity and cause-effect problem of networks and venture performance is a serious methodological deficiency in the network-based entrepreneurship research. Using the collected information on the duration of each respondent-alter tie, I calculated the average dyadic (ego-alter) tie age for each respondent - the sum of years known of each alter divided by the number of alters, and compared it with the mean firm age. While the mean respondent-alter tie age is 5 years (S.D.=3.53), the mean firm age is 3.33 years (S.D.=1.44). On average, the entrepreneurs knew the network contacts for 2.7 years before venture formation. This shows that the vast majority of ties were established before firm was registered. Further, I calculated the percent of those ties that were established after the venture was founded 'post start-up ties' and examined their effects on product portfolio and profit growth. The results of the linear regression analysis presented in Table 6 reveal that the effects of post start-up ties on product portfolio and profit growth are not statistically significant. Based on these findings, I assume that network's structural holes affected the dependent variables rather than outcome variables influenced networks.

Table 6. Linear regression analysis: Post start-up ties, product portfolio, and profit growth of new software ventures $(\mathrm{N}=159)$

$\begin{array}{cc}\text { Product portfolio } & \text { Profit growth \% } \\ \text { Model } 1 & \text { Model } 2\end{array}$

\section{Control variables}

Firm age

Firm size

Ownership

Venture capital
$-0.13 \dagger \quad 0.27 * *$

$0.11 \dagger$

$-0.09$

$-0.06 \quad 0.11$

$0.12 * \quad 0.15 \dagger$


Structural holes

$\begin{array}{lcc}\text { Entrepreneur's age } & 0.08 & -0.18^{*} \\ \text { Entrepreneur's education } & -0.06 & -0.07 \\ \text { Network size } & 0.08 & 0.19^{*} \\ \text { Structural holes \% } & 0.70^{* * *} & -0.26 \dagger \\ \text { China } & -0.11 & -0.07 \\ \text { Product portfolio } & & -0.04\end{array}$

Two-way interactions

Structural holes \%* China $\quad-0.53 * * *$

Structural holes \%* Product portfolio $\quad-0.04$

\section{Independent variable}

Post start-up ties \%

$0.12 \quad 0.00$

Model $F$

$15.22 * * * \quad 1.95^{*}$

Adjusted $R$ square

$0.50 \quad 0.07$

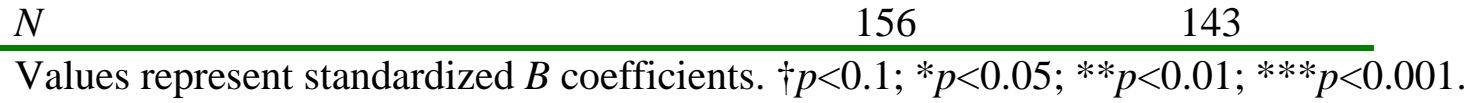
DISCUSSION

This study examined the effect of network's structural holes on product portfolio and profit growth of new software ventures. I found that structural holes in entrepreneur's personal networks facilitate product development because they provide access to nonredundant information, diverse resources, and third-party referrals. The entrepreneurs whose networks are rich in structural holes combine and re-combine various program codes, modules, functions, design features, and languages to produce software applications for numerous market segments.

I theorized that the effect of structural holes on product portfolio is stronger in Russia than in China due to the polycentricity of institutions. The rapid deinstitutionalization in Russia led to low-density networks rich in structural holes, and the Russian social norms accept entrepreneurial brokerage. Therefore, Russian entrepreneurs benefit more from network’s structural holes. In contrast, the gradual 
Structural holes

institutionalization in China is reflected in cohesive networks poor in structural holes, and the Chinese group-oriented social customs penalize brokers. Thus, Chinese entrepreneurs do not benefit from structural holes as much as Russians because the cost of building and maintaining loose-knit networks is greater than the return from these networks in China.

The study revealed that network’s structural holes inhibit profit growth in the early years of venture development because of the coordination and communication problems, constrained resource mobilization, and inconsistent strategies.

\section{Contributions}

This study contributes to the international entrepreneurship literature and the structural holes argument of network theory. The study showed that the effect of structural holes on dependent variable is moderated by polycentric and diverse institutions in China and Russia. The perspective of institutional polycentrism is a relatively new theoretical explanation in the entrepreneurship research. This study is one of the first studies that examined effects of structural holes in two country contexts China and Russia. Therefore, this article makes both theoretical and empirical contributions to comparative studies of entrepreneurs and entrepreneurship processes in different contexts - a relatively under-researched topic even within the international entrepreneurship literature (Cumming et al., 2009). Further, this study is among first studies that examined the effect of structural holes in entrepreneur's personal (egocentric) networks on venture development and performance. The findings on the main positive and negative effects, and indirect (interaction) negative effects of structural holes is a refinement and modification of the structural holes argument because it identifies 
Structural holes

boundary conditions for network structural holes' effect. Thus, I claim a contribution to the structural holes argument of social network theory.

In addition, these findings have implications for the institutional theory literature. This study tentatively suggests that institutional transformation in emerging economies may not be always an isomorphic and unicentric process that results in institutional homogeneity. On the contrary, it may contain dual tendencies of isomorphism and polycentrism that reflected in institutional diversities around the world.

\section{Research implications}

While we know that structural holes help entrepreneurs to develop software products, the question which of the three mechanisms - information, resources and referrals, plays what role in product development remains unanswered. Therefore, further research should provide fine-tuned analysis on the actual roles of various network mechanisms for product portfolio and new venture performance. Does access to information and knowledge generate more benefits than access to diverse tangible resources or third-party referrals? Do combinations of three mechanisms produce greater benefits for entrepreneurs?

In this study, I assumed that the presence of structural holes in networks affects the outcome variables. However, further studies should distinguish between the presence of structural holes and the spanning of structural holes - active brokerage, and examine when and why those actors who have loose-knit networks actively span structural holes to generate profits. The entrepreneur may play different roles in spanning structural holes: the role of the integrator who connects sides and creates value for all triad members (Xiao and Tsui, 2007), and the role of the controller who deliberately plays 
Structural holes

actors against one another and generates profits for him or herself only (Burt, 1992).

What role a network entrepreneur assumes is likely to depend on personality, cultural and social norms, and local settings.

If network’s structural holes have a negative effect on financial performance in the early stages of venture development, a logical question for future research is that do structural holes affect positively financial performance in later stages, for example, obtaining bank loans or pre-IPO stage. Is the effect of structural holes on outcome variables linear or curvilinear? Current research suggests that network's structural holes change over time (Batjargal, 2010). Therefore, why and how structural holes evolve, and what implications it has for dependent variables are questions that can be addressed in further studies.

Future research should assess effects of institutions on network structure by measuring institutions directly. Does institutional void (Khanna and Palepu, 2000) generate entrepreneurial networks rich in structural holes? Does incremental institutional evolution (Scott, 2000) produce dense and tight-knit networks that contain fewer structural holes? Is the institutional transformation in emerging economies an isomorphic and unicentric process that results in increasingly similar institutions in the developed and developing economies?

The newly emergent literature on institutional diversity suggests that formal and informal institutions across different countries and cultures are diverse and polycentric. This diversity and polycentricity is likely to persist as long as institutions are embedded in local beliefs, knowledge, and settings (North, 2005; Ostrom, 1990; 2005). The postulate of institutional polycentrism is a promising explanation in institution-based 
Structural holes

management and entrepreneurship research because it is complementary to the influential perspective of institutional isomorphism (DiMaggio and Powell, 1983). This idea is likely to be a beneficial theoretical framework for international and comparative entrepreneurship research. Institutional transformation is likely to contain dual tendencies of isomorphism, i.e., institutions in different countries become similar over time like international accounting regulations, and polycentrism, i.e., unique local features and characteristics of institutions in various countries are likely to persist over time like rules governing common-pool resources. Do diverse and polycentric institutions in different countries produce dissimilar network patterns (Ostrom et al., 1993)? Another question for further research is whether formal institutions, e.g., regulations, influence more network structure while informal institutions such as social norms affect more relational aspect, e.g., trust and tie strength, of networks. The above discussed questions should be addressed in future research.

\section{Limitations}

Like any other study in social sciences, this study has its limitations. I used country dummy variables for measuring institutions. Therefore, there is a possibility of an alternative explanation for the findings. I acknowledge this as a shortcoming. The software industries in China and Russia are young, and therefore, institutional, regulatory and market immaturity may have affected these results, although I assume that all the entrepreneurs are exposed to the same country conditions to the same extent. The sample size is relatively small. The product portfolio measurement is subjective, although this measurement suits the country and industry contexts because the Chinese and Russian software industries are new industries in relatively new market economies. Although I 
Structural holes

validated the data through phone calls and cross-checks, the potential common methods bias remains an issue. The interviewed sample may be venture survival biased. However, I think the potential bias is not systematic to affect the results for the following reasons. The empirical evidence suggests that financial performance does not predict firm survival in emerging economies (Lyles, Saxton and Watson, 2004). Thus, some financially distressed ventures may survive longer while other financially sound firms may discontinue. In addition, I control for firm age. The linear regression results in Table 3 show that the effect of firm age on product portfolio is not statistically significant, and the effect of firm age on profit growth is positive and statistically significant (Model 5). I checked the distribution of firm age, and found that the distribution is not skewed towards older firms in any significant ways. These findings indirectly suggest that potential survival bias is not serious in this study. Finally, I use profit growth percent in one year (second revenue year), and I acknowledge that this is a limitation.

\section{CONCLUSION}

This study argued that the effect of network's structural holes on dependent variables is contingent upon country institutional context due to the polycentric nature of institutional transformation. Specifically, the usefulness of structural holes for entrepreneurial success depends on local institutional characteristics, and venture development stage. Structural holes may be more valuable in more diverse and polycentric institutional environments, and may be less useful for financial success of ventures in the early stages of their development. Future research on entrepreneurial networks should pay a greater attention to local institutional factors that influence network patterns. 


\section{ACKNOWLEDGEMENTS}

I would like to thank Tim Colton, Celine Shen, Liz Tarlow, Weiying Zhang, Shanli Zhu, Changqi Wu and my research assistants. I appreciate the valuable comments and suggestions of Professor Michael Hitt - the co-editor, Philip Kim, and three anonymous reviewers.

\section{REFERENCES}

Aidis R, Estrin S, Mickiewicz T. 2008. Institutions and entrepreneurship development in Russia: A comparative perspective. Journal of Business Venturing 23 (6): 656-672.

Aldrich H, Kim P. 2007. Small worlds, infinite possibilities? How social networks affect entrepreneurial team formation and search. Strategic Entrepreneurship Journal 1: 147-165.

Batjargal B. 1998. New Entrepreneurs in Post-Soviet Russia, Unpublished DPhil thesis, University of Oxford, Oxford, U.K.

Batjargal, B. 2000. Effects of networks on entrepreneurial performance in a transition economy: The case of Russia. In Frontiers of Entrepreneurship Research 2000, Reynolds P, Autio E, Brush C, Bygrave W, Manigart S, Sapienza H, Shaver K (eds). Babson, MA; 97-110.

Batjargal, B. 2003a. Social capital and entrepreneurial performance in Russia: A longitudinal study. Organization Studies 24 (4): 535-556.

Batjargal, B. 2003b. Internet entrepreneurship in an emerging market: Networks and performance of Internet startups. In Best Paper Proceedings of the Annual Meeting of the Academy of Management (CD), Nagao DH (ed). ISSN 1543-8643.

Batjargal, B. 2005. Entrepreneurial versatility, resources and firm performance in Russia: A panel study. International Journal of Entrepreneurship and Innovation Management, Special Issue on Transition Economies 5 (3/4): 284-297.

Batjargal, B. 2006. The dynamics of entrepreneurs' networks in a transition economy: The case of Russia. Entrepreneurship and Regional Development 18 (4): 305-320.

Batjargal, B. 2007a. Internet entrepreneurship: Social capital, human capital, and performance of Internet ventures in China. Research Policy 36 (5): 605-618.

Batjargal, B. 2007b. Network triads: Transitivity, referral, and venture capital decisions in China and Russia. Journal of International Business Studies 38 (6): 998-1012. 
Structural holes

Batjargal, B. 2007c. Comparative social capital: Networks of entrepreneurs and venture capitalists in China and Russia. Management and Organization Review 3 (3): 397419.

Batjargal, B. 2008. Networking: The Difference between Russian and Chinese entrepreneurs. Harvard Business Review 86 (10): 32.

Batjargal, B. 2010. Network dynamics and venture performance in China: A longitudinal study. Entrepreneurship and Regional Development forthcoming.

Batjargal B, Liu M. 2004. Entrepreneurs' access to private equity in China: The role of social capital. Organization Science, Special Issue on China 15 (2): 159-172.

Batjargal B, Hitt M, Webb J, Arregle JL, Miller T. 2009. Women and men entrepreneurs' social networks and new venture performance across cultures. In Best Paper Proceedings of the Annual Meeting of the Academy of Management, Solomon G, (ed). Chicago, Ill.

Baum J, Calabrese T, Silverman B. 2000. Don’t go it alone: Alliance network composition and startups' performance in Canadian biotechnology. Strategic Management Journal 21 (3): 267-294.

Belliveau M, O’Reilly C, Wade J. 1996. Social capital at the top: Effects of social similarity and status on CEO compensation. Academy of Management Journal 39: 1568-1593.

Bian, Y. 1997. Bringing strong ties back in: Indirect ties, network bridges, and job searches in China. American Sociological Review 62: 366-385.

Blanchard O, Kremer M. 1997. Disorganization. The Quarterly Journal of Economics 112 (4): 1091-1126.

Brass D, Galaskiewicz J, Greve H, Tsai W. 2004. Taking stock of networks and organizations: A multilevel perspective. Academy of Management Journal 47 (6): 795-817.

Burgess N, Travis L. 2005. Offshoring in Russia still a work in progress. AMR Research, www.amrresearch.com, [22 January 2010].

Burt R. 1992. Structural Holes: the Social Structure of Competition. Harvard University Press: Cambridge, MA.

Burt, R. 2004. Structural holes and good ideas. American Journal of Sociology 110 (2): 349-399.

Business Weekly, 2003. Beijing. April 1-7: 11. 
Structural holes

Coleman G, Verbruggen R. 1998. A quality software process for rapid application development. Software Quality Journal 7: 107-122.

Colyvas J, Powell W. 2006. Roads to institutionalization: The remaking of boundaries between public and private science. In Research in Organizational Behavior, Staw B (ed). JAI Press, 27: 305-353.

Cumming D, Sapienza H, Siegel D, Wright M. 2009. International entrepreneurship: managerial and policy implications. Strategic Entrepreneurship Journal 3: 283-296.

Dai, J. 2002. Newly born private enterprise owners in China. Social Sciences in China 23: $124-134$.

Djankov S, QianY, Roland G, Zhuravskaya E. 2006. Entrepreneurship in China and Russia compared. Journal of European Economic Association 4 (2-3): 352-365.

DiMaggio P, Powell W. 1983. The iron cage revisited: institutional isomorphism and collective rationality in organizational fields. American Sociological Review 48 (2): 147-160.

Economy of Russia, 2010. Wikipedia, The Free Encyclopedia, www.en.wikipedia.org [22 January 2010].

Eisenhardt K, Schoonhoven C. 1996. Resource-based view of strategic alliance formation: strategic and social effects in entrepreneurial firms. Organization Science 7: $136-150$.

Ekspert, 2003. Moscow, June 23: 85.

Emirbayer M, Goodwin J. 1994. Network analysis, culture, and the problem of agency. American Journal of Sociology 99 (6): 1411-1454.

Goldman, M. 2003. The piratization of Russia, Russian Reform Goes Awry, Routledge: New York.

Goldman, M. 2008. Petrostate: Putin, Power, and the New Russia, Oxford University Press: Oxford, U.K.

Granovetter, M. 1983. The strength of weak ties: A network theory revisited. Sociological Theory 1: 201-233.

Guseva A, Rona-Tas A. 2001. Uncertainty, risk, and trust: Russian and American credit card markets compared. American Sociological Review 66: 623-46. 
Structural holes

Fernandez R, Castilla E, Moore P, 2000. Social capital at work: Networks and employment at a phone center. American Journal of Sociology 105 (5): 1288-1356.

Frye T. 2000. Brokers and Bureaucrats: Building Market Institutions in Russia. University of Michigan Press: Ann Arbor, Michigan.

Khanna T, Palepu K. 2000. The future of business groups in emerging markets: Long-run evidence from Chile. Academy of Management Journal 43 (3): 268-285.

Kharkhordin O, Gerber T. 1994. Russian directors' business ethic: A study of industrial enterprises in St Petersburg 1993. Europe-Asia Studies 46 (7): 1075-1107.

Hargadon A, Sutton R, 1997. Technology brokering and innovation in a product development firm. Administrative Science Quarterly 42: 716-749.

Hitt M, Ahlstrom D, Dacin T, Levitas E, Svobodina L. 2004. The institutional effects on strategic alliance partner selection in transition economies: China versus Russia. Organization Science, Special Issue on China 15 (2): 173-185.

Hofstede G, Bond M. 1988. The Confucius connections: From cultural roots to economic growth. Organizational Dynamics 16 (4): 5-21.

James LR, Demaree R, Wolf G. 1984. Estimating within-group inter-rater reliability with and without response bias. Journal of Applied Psychology 69: 85-98.

Ledeneva A. 1998. Russia's Economy of Favours: Blat, Networking and Informal Exchange. Cambridge University Press: Cambridge, U.K.

Lin N. 2001. Social Capital a Theory of Social Structure and Action. Cambridge University Press: Cambridge, U.K.

Lin N, Dumin M. 1986. Access to occupations through social ties. Social Networks 8: 365-385.

Lyles M, Saxton T, Watson K. 2004. Venture survival in a transitional economy. Journal of Management 30 (3): 351-375.

Marsden, P. 1982. Brokerage behavior in restricted exchange networks. In Social Structure and Network Analysis, Marsden P, Lin N, (eds). Sage: Beverly Hills; 201218.

Marsden, P. 1990. Network data and measurement. Annual Review of Sociology 16: 435463. 
Structural holes

Marsden, P. 2005. Recent developments in network measurement. In Models and Methods in Social Network Analysis, Carrington P, Scott J, Wasserman S (eds). Cambridge University Press: New York; 8-30.

Nee, V. 1992. Organizational dynamics of market transition: Hybrid forms, property rights, and mixed economy in China. Administrative Science Quarterly 37: 1-27.

North, D. 1990. Institutions, Institutional Change and Economic Performance. Cambridge University Press: Cambridge, U.K.

North, D. 2005. Understanding the Process of Economic Change. Princeton University Press: Princeton, NJ.

Oliver, C. 1992. The Antecendents of deinstitutionalization. Organization Studies 13 (4): 563-588.

Ostrom, E. 1990. Governing the Commons: the Evolution of Institutions for Collective Action. Cambridge University Press: Cambridge, U.K.

Ostrom, E. 2005. Understanding Institutional Diversity, Princeton University Press: Princeton, NJ.

Ostrom E, Schroeder L, Wynne L. 1993. Institutional Incentives and Sustainable Development: Infrastructure Policies in Perspective. Westview Press: Boulder.

Park S, Luo Y. 2001. Guanxi and organizational dynamics: Organizational networking in Chinese firms. Strategic Management Journal 22: 455-477.

People’s Daily, 2004. Beijing: January 15.

Podolny J, Baron J. 1997. Resources and relationships: social networks and mobility in the work place. American Sociological Review 62: 673-693.

Ralston D, Holt D, Terpstra R, Kai-Cheng Y. 1997. The impact of national culture and economic ideology on managerial work values: A study of the United States, Russia, Japan, and China. Journal of International Business Studies 1: 177-207.

Renzulli L, Aldrich H, Moody J. 2000. Family matters: gender, networks, and entrepreneurial outcomes. Social Forces 79 (2): 523-546.

Reynolds P, White S. 1997. The Entrepreneurial Process: Economic Growth, Men, Women, and Minorities. Quorum Books: Westport, CT.

Rothaermel F, Hitt M, Jobe L. 2006. Balancing vertical integration and strategic outsourcing: effects on product portfolio, product success, and firm performance. Strategic Management Journal 27: 1033-1056. 
Structural holes

Ruef M, Aldrich H, Carter N. 2003. The structure of founding teams: homophily, strong ties, and isolation among US entrepreneurs. American Sociological Review 68 (21): 195-222.

Saxenian A, Quan X. 2005. Guanxi and government: The Chinese software industry in transition. In The Software Industry in Emerging Market, Commander S (ed).

Edward Elgar: Cheltenham, U.K.:73-132.

Schach, S. 2002.Object-oriented and Classical Software Engineering, McGraw Hill: New York.

Scott, R. 2000. The changing world of Chinese enterprise: An institutional perspective. In Management and Organizations in the Chinese Context, Li JT, Tsui A, Weldon E (eds). St. Martin's Press: New York; 59-78.

Scott, R. 2001. Institutions and Organizations. London: Sage Publications.

Sedaitis, J. 1998. The alliances of spin-offs versus start-ups: social ties in the genesis of post-Soviet alliances. Organization Science 9: 368-381.

Segal, A. 2003. Digital Dragon: High Technology Enterprises in China. Cornell University Press: Ithaca.

Shleifer, A. 2005. A Normal Country, Russia after Communism. Harvard University Press: Cambridge, MA.

Spicer A, Pyle W. 2002. Institutions and the vicious circle of distrust in the Russian household deposit market, 1992-1999. In Advances in Strategic Management, 19: 373-398, Elsevier Science.

Software industry in China, 2008. Wikipedia, The Free Encyclopedia, www.en.wikipedia.org [12 December 2008].

Stam, W. 2010. Industry event participation and network brokerage among entrepreneurial ventures. Journal of Management Studies, forthcoming.

Stuart T, Hoang H, Hybels R. 1999. Interorganizational endorsement and the performance of entrepreneurial ventures. Administrative Science Quarterly 44: 315349.

Stuart T, Sorenson O. 2007. Strategic networks and entrepreneurial ventures. Strategic Entrepreneurship Journal 1: 211-227.

Tschang T, Xue L. 2005. The Chinese Software Industry. In From Underdogs to Tigers: The Rise and Growth of the Software Industry in Brazil, China, India, Ireland and Israel, Arora A, Gambardella A (eds). Oxford University Press: Oxford, U.K. 
Structural holes

Xiao Z, Tsui A. 2007. When brokers may not work: The culture contingency of social capital. Administrative Science Quarterly 52 (1): 1-31.

Xin K, Pearce J. 1996. Guanxi: Connections as substitutes for formal institutional support. Academy of Management Journal, 39: 1641-1658.

Zahra S, Ireland D, Hitt M. 2000. International expansion by new venture firms: International diversity, mode of market entry, technological learning, and performance. Academy of Management Journal 43: 925-950.

Zhou, Y. 2007. The Inside Story of China's High Tech Industry: Making Silicon Valley in Beijing. Rowman and Littlefield Publishers: New York.

\section{Appendix: The matrix that captures network structure}

\begin{tabular}{|c|c|c|c|c|c|c|c|c|}
\hline & Names & & & & & & & \\
\hline 1 & & 1 & & & & & & \\
\hline 2 & & E D & 2 & & & & & \\
\hline 3 & & E D & E D & 3 & & & & \\
\hline 4 & & E D & E D & E D & 4 & & & \\
\hline 5 & & E D & E D & E D & E D & 5 & & \\
\hline 6 & & E D & E D & E D & E D & E D & 6 & \\
\hline 7 & & E D & E D & E D & E D & E D & E D & 7 \\
\hline 8 & & E D & E D & E D & E D & E D & E D & E D \\
\hline
\end{tabular}




\section{DAVIDSON INSTITUTE WORKING PAPER SERIES - Most Recent Papers}

The entire Working Paper Series may be downloaded free of charge at: www.wdi.umich.edu

CURRENT AS OF 5/29/12

\begin{tabular}{|c|c|c|}
\hline Publication & Authors & Date \\
\hline $\begin{array}{l}\text { No. 1033: The Effects Of Network's Structural Holes: Polycentric } \\
\text { Institutions, Product Portfolio, And New Venture Growth In China And } \\
\text { Russia }\end{array}$ & Bat Batjargal & May 2012 \\
\hline $\begin{array}{l}\text { No. 1032: The Bulgarian Foreign and Domestic Debt - A No-Arbitrage } \\
\text { Macrofinancial View }\end{array}$ & Vilimir Yordanov & $\begin{array}{l}\text { March } \\
2012\end{array}$ \\
\hline $\begin{array}{l}\text { No. 1031: Macroeconomic Shock Synchronization in the East African } \\
\text { Community }\end{array}$ & $\begin{array}{l}\text { Albert Mafusire \& Zuzana } \\
\text { Brixiova }\end{array}$ & $\begin{array}{l}\text { March } \\
2012\end{array}$ \\
\hline $\begin{array}{l}\text { No. 1030: Does Human Capital Endowment of FDI Recipient Countries } \\
\text { Really Matter? Evidence from Cross-Country Firm Level Data }\end{array}$ & $\begin{array}{l}\text { Sumon K. Bhaumik \& } \\
\text { Ralitza Dimova } \\
\end{array}$ & Feb 2012 \\
\hline $\begin{array}{l}\text { No. 1029: Does institutional quality affect firm performance? } \\
\text { Insights from a semiparametric approach }\end{array}$ & $\begin{array}{l}\text { Sumon K. Bhaumik, Ralitza } \\
\text { Dimova, Subal C. Kumbhakar } \\
\text { \& Kai Sun } \\
\end{array}$ & Feb 2012 \\
\hline $\begin{array}{l}\text { No. 1028: International Stock Market Integration: Central and South } \\
\text { Eastern Europe Compared }\end{array}$ & $\begin{array}{l}\text { Roman Horvath \& } \\
\text { Dragan Petrovski }\end{array}$ & Feb 2012 \\
\hline No. 1027: LABOUR MARKET REFORMS AND OUTCOMES IN ESTONIA & Zuzana Brixiova and Balazs Egert & Feb 2012 \\
\hline $\begin{array}{l}\text { No. 1026: The Impact Of Capital Measurement Error Correction On } \\
\text { Firm-Level Production Function Estimation }\end{array}$ & Lubomir Lizal \& Kamil Galuscak & Jan 2012 \\
\hline $\begin{array}{l}\text { No. 1025: CREDIT CONSTRAINTS AND PRODUCTIVE ENTREPRENEURSHIP IN } \\
\text { AFRICA }\end{array}$ & $\begin{array}{l}\text { Mina Baliamoune-Lutz, Zuzana } \\
\text { Brixiová \& Léonce Ndikumana }\end{array}$ & Dec 2011 \\
\hline No. 1024: Entry Costs and Increasing Trade & $\begin{array}{l}\text { William F. Lincoln and } \\
\text { Andrew McCallum }\end{array}$ & Nov 2011 \\
\hline $\begin{array}{l}\text { No. 1023: The Dependence Of CEECs On Foreign Bank Claims: Direct } \\
\text { And Indirect Risks Of Capital Withdrawal }\end{array}$ & $\begin{array}{l}\text { Sophie Brana and } \\
\text { Delphine Lahet }\end{array}$ & Nov 2011 \\
\hline $\begin{array}{l}\text { No.1022: The Development Effects Of Natural Resources: } \\
\text { A Geographical Dimension }\end{array}$ & $\begin{array}{l}\text { Fabrizio Carmignani \& } \\
\text { Abdur Chowdhury }\end{array}$ & Nov 2011 \\
\hline $\begin{array}{l}\text { No. 1021: How to Stir Up FDI Spillovers: Evidence from a Large Meta- } \\
\text { Analysis }\end{array}$ & Tomas Havranek \& Zuzana Irsova & Nov 2011 \\
\hline $\begin{array}{l}\text { No. 1020: Volatility transmission in emerging European foreign exchange } \\
\text { markets }\end{array}$ & $\begin{array}{l}\text { Evzen Kocenda, Vit Bubak \& } \\
\text { Filip Zikes } \\
\end{array}$ & July 2011 \\
\hline $\begin{array}{l}\text { No. 1019: Whither human capital? The woeful tale of transition to tertiary } \\
\text { education in India }\end{array}$ & $\begin{array}{l}\text { Sumon Bhaumik and } \\
\text { Manisha Chakrabarty }\end{array}$ & July 2011 \\
\hline $\begin{array}{l}\text { No. 1018: From Prosperity to Depression: Bulgaria and Romania } \\
\text { (1996/97 - 2010) }\end{array}$ & $\begin{array}{l}\text { Nikolay Nenovsky, Kiril Tochkov } \\
\text { and Camelia Turcu }\end{array}$ & May 2011 \\
\hline $\begin{array}{l}\text { No. 1017: Institutions, Governance and Technology catch-up in North } \\
\text { Africa }\end{array}$ & Imed Drine & May 2011 \\
\hline No. 1016: Financial Efficiency and the Ownership of Czech Firms & $\begin{array}{l}\text { Evzen Kocenda, Jan Hanousek } \\
\text { and Michal Masika }\end{array}$ & May 2011 \\
\hline $\begin{array}{l}\text { No. 1015: Default Predictors in Retail Credit Scoring: Evidence from } \\
\text { Czech Banking Data }\end{array}$ & Evzen Kocenda \& Martin Vojtek & April 2011 \\
\hline $\begin{array}{l}\text { No. 1014: Exchange Rate Pass-Through in Transition Economies: The } \\
\text { Case of Republic of Macedonia }\end{array}$ & Besnik Fetai & April 2011 \\
\hline $\begin{array}{l}\text { No. 1013: Establishing Data Collection Procedures Equivalence in } \\
\text { International Business Research }\end{array}$ & $\begin{array}{l}\text { Agnieszka Chidlow \& } \\
\text { Pervez N. Ghauri }\end{array}$ & $\begin{array}{c}\text { March } \\
2011\end{array}$ \\
\hline $\begin{array}{l}\text { No. 1012: The Link between Innovation and Productivity in Estonia's } \\
\text { Service Sectors }\end{array}$ & Priit Vahter \& Jaan Masso & $\begin{array}{c}\text { March } \\
2011\end{array}$ \\
\hline $\begin{array}{l}\text { No. 1011: Learning by exporting: evidence based on data of knowledge } \\
\text { flows from innovation surveys in Estonia }\end{array}$ & Priit Vahter & Feb 2011 \\
\hline $\begin{array}{l}\text { No. 1010: Firm Investment \& Credit Constraints in India, } 1997 \text { - 2006: } \\
\text { A stochastic frontier approach }\end{array}$ & $\begin{array}{l}\text { Sumon Bhaumik, Pranab Kumar } \\
\text { Das and Subal C. Kumbhakar }\end{array}$ & Jan 2011 \\
\hline No. 1009: Industrial Enlargement And Competitiveness Index & Art Kovacic & Jan 2011 \\
\hline
\end{tabular}

